\title{
An evaluation of high temperature tensile properties for a magnesium AZ31 alloy processed by high-pressure torsion
}

\author{
Y. Huang ${ }^{1 \dagger}$, P.H.R. Pereira ${ }^{1,2}$, R.B. Figueiredo ${ }^{3}$, T. Baudin ${ }^{4}$, A.-L. Helbert ${ }^{4}$, \\ F. Brisset ${ }^{4}$, T.G. Langdon ${ }^{1,5}$ \\ †y.huang@soton.ac.uk \\ ${ }^{1}$ Materials Research Group, Faculty of Engineering and the Environment, University of Southampton, \\ Southampton SO17 1BJ, U.K. \\ ${ }^{2}$ CAPES Foundation, Ministry of Education of Brazil, Brasília - DF 70040-020, Brazil \\ ${ }^{3}$ Department of Materials Engineering and Civil Construction, Federal University of Minas Gerais, \\ Belo Horizonte, MG 31270-901, Brazil \\ ${ }^{4}$ ICMMO, UMR CNRS 8182 - Bât 410, Université Paris-Sud, 91405 Orsay Cedex, France \\ ${ }^{5}$ Departments of Aerospace \& Mechanical Engineering and Materials Science, University of Southern California, \\ Los Angeles, CA 90089-1453, U.S.A.
}

\begin{abstract}
A magnesium alloy AZ31 was processed by high-pressure torsion (HPT) at room temperature. Microstructure investigations show the material has a grain size as fine as $\sim 450 \mathrm{~nm}$ after 5 turns of HPT processing. X-ray texture measurements show most grains have the $\{0001\}<$ uvtw $>$ fibre, with their c-axis parallel to the HPT torsion axis. Tensile specimens were cut from HPT disc and pulled to failure over a range of strain rates $\left(4.5 \times 10^{-5}, 1.3 \times 10^{-4}, 1.3 \times 10^{-3}\right.$ and $\left.1.3 \times 10^{-2} \mathrm{~s}^{-1}\right)$ at temperatures of 623 and $673 \mathrm{~K}$. The tensile elongations from HPT specimens are lower than for published results using equal-channel angular processing (ECAP) specimens although AZ31 has a finer grain size after HPT than after ECAP. The reasons for the lower elongations in HPT specimens are related to the thermal stability of the processed microstructure, the texture components and the tensile specimen size. Earlier investigations confirmed there was significant grain growth at 623 and $673 \mathrm{~K}$ in HPT samples, which would contribute to the low ductility of AZ31 in tensile testing. The main $\{0001\}<$ uvtw $>$ fibre in HPT samples means in tensile specimens most grains have their basal plane parallel to the surface of the tensile specimen, leading to the low ductility because the critical resolved shear stress does not operate on the basal plane due to the small Schmid factor that is nearly zero. The tensile specimen thickness in HPT is thinner than in ECAP and it is known that the ductility decreases when reducing the specimen thickness.
\end{abstract}

Keywords: AZ31, high-pressure torsion, magnesium alloy, tensile properties

\section{Оценка высокотемпературных механических свойств при растяжении магниевого сплава AZ31, подвергнутого кручению под высоким давлением}

Магниевый сплав AZ31 был подвергнут кручению под высоким давлением (КВД) при комнатной температуре. Микроструктурные исследования показали, что материал имеет размер зерен около 450 нм после 5 оборотов КВД. Измерения текстуры рентгенографическим методом показали, что большинство зерен имеют волокнистую текстуру $\{0001\}<$ uvtw> c осью $c$, параллельной оси кручения. Из дисков, подвергнутых КВД, вырезаны образцы для испытаний растяжением, которые испытаны до разрушения в интервале скоростей деформации $\left(4.5 \times 10^{-5}, 1.3 \times 10^{-4}, 1.3 \times 10^{-3}\right.$ и $1.3 \times 10^{-2} \mathrm{c}^{-1}$ ) при температурах 623 и $673 \mathrm{~K}$. Значения удлинения при растяжении образцов после КВД оказались ниже, чем опубликованные значения, полученные на образцах, подвергнутых равноканальному угловому прессованию (РКУП), хотя сплав AZ31 имеет меньший размер зерен после КВД, чем после РКУП. Причина более низких значений удлинения образцов после КВД связана с термической стабильностью микроструктуры, текстурными компонентами и размерами образцов для растяжения. Прежние исследования показали, что в образцах после КВД имеет место значительный рост зерен при 623 и 673 К; это вызывает снижение пластичности сплава AZ31 при растяжении. Главная текстурная компонента $\{0001\}<\mathrm{uvtw>}$ в образцах после КВД означает, что в образцах для растяжения большинство зерен имеет ориентацию базальной плоскости, параллельную поверхности образца. Это также приводит к снижению пластичности, так как на базальной плоскости не действует критическое приведенное напряжение сдвига, поскольку фактор Шмидта низок и близок к нулю. Образцы для растяжения после КВД тоньше, чем после РКУП. Известно, что пластичность снижается при уменьшении толщины образцов.

Ключевые слова: AZ31, кручение под высоким давлением, магниевый сплав, свойства при растяжении 


\section{Introduction}

Magnesium alloys are attractive for use as structural materials due to their high strength to weight ratio. Because of the hexagonal close-packed (HCP) crystal structure and limited slip systems at room temperature, $\mathrm{Mg}$ alloys are usually processed at moderate or high temperatures [1] by traditional thermo-mechanical processing. However, the total deformation achieved by conventional thermo-mechanical processing is severely limited by the reduction in the cross-sectional areas of the samples. As a result, this type of processing is usually not sufficient to promote a homogeneous refinement of the initial coarse structure of the material.

Equal-channel angular pressing (ECAP) and highpressure torsion (HPT) are most efficient severe plastic deformation (SPD) techniques for producing high-strength ultrafine-grained and nanostructured materials [2-4]. The sample sizes are not changed during ECAP or HPT processing and therefore in principle the materials can be subjected to as many passes of ECAP processing or as many turns of HPT processing in order to achieve significant grain refinement and strength improvement. The ECAP process is not continuous while HPT permits the introduction of extremely large strains in a single operation. In HPT, a very high compression pressure is applied on a disc and the generated large frictional force allows the disc material to undergo torsional deformation [4]. It was shown through experiments that the grains produced by HPT are generally smaller than those achieved using ECAP [5-7] and, accordingly, HPT processing is therefore advancing rapidly to become a significant processing procedure.

Superplastic metals generally have grain sizes in the range of $\sim 3-5 \mu \mathrm{m}$ [8]. However, processing through the application of ECAP or HPT produces grain sizes in the submicrometer range [2] and, if these grains are stable at elevated temperatures, these materials may exhibit excellent superplastic properties. There exist several published reports on tensile properties of ECAP processed AZ31 [9-11] but there are no published reports on the tensile properties of HPT processed AZ31. Therefore, this investigation was initiated to examine the high temperature tensile properties of a magnesium AZ31 alloy processed by HPT.

\section{Experimental material and procedures}

The material used in this study was a commercial AZ31 alloy (Mg-3\%Al-1\%Zn) supplied by Timminco Corporation (now Applied Magnesium International), Aurora, CO. The AZ31 alloy was received in the form of extruded rods having diameters of $10 \mathrm{~mm}$. In the as-received condition, the Vickers microhardness, Hv, was $\sim 55$ [12]. The extruded rods were sliced into discs with thicknesses of $\sim 1.25 \mathrm{~mm}$ and then ground with abrasive papers to final thicknesses of $\sim 0.82 \mathrm{~mm}$.

The discs were processed by HPT under quasi-constrained conditions [13] through total numbers of turns, N, of 1 and 5 at room temperature using an imposed pressure of 6.0 $\mathrm{GPa}$ and a rotational speed for the lower anvil of $1 \mathrm{rpm}$. Following HPT, the processed discs were ground and polished for microhardness measurements. The Vickers microhard- ness, Hv, was measured using a Zwick Indentic microhardness tester equipped with a Vickers indenter. The hardness measurements used a load of $200 \mathrm{gf}$ and dwell times of $10 \mathrm{~s}$. These measurements were taken at positions along the disc diameter separated by incremental distances of $0.3 \mathrm{~mm}$ with four individual points recorded around each selected position separated from this position by distances of $0.15 \mathrm{~mm}$. These measurements were used to provide the variations of hardness across each disc together with the associated error bars recorded at the $95 \%$ level.

Electron back-scatter diffraction (EBSD) was used to characterize the grain structures before and after HPT processing. The experimental results were collected using a scanning electron microscope FEG-SEM SUPRA 55 VP operating at $15 \mathrm{kV}$ equipped with an $\mathrm{OIM}^{\mathrm{TM}}$ system. The sample preparation of this $\mathrm{Mg}$ alloy for EBSD is difficult due to the low density of the Kikuchi diffraction patterns. Final polishing was performed using an alumina suspension to prepare the specimens for electro-polishing in an AC2 electrolyte provided by Struers. The distorted surface layer with a thickness of several micrometers was removed by Ar ion milling. Representative regions were mapped using a step size of $0.25 \mu \mathrm{m}$ for the initial state and $25 \mathrm{~nm}$ for the discs processed by HPT.

For comparison, the crystallographic texture was measured at the disc half-radius on an area of $1 \times 2 \mathrm{~mm}^{2}$ by X-ray diffraction in a Siemens goniometer system. The X-ray radiation used was cobalt $\mathrm{K} \alpha$ and seven $\{0002\},\{11 \overline{2} 0\},\{01 \overline{1} 1\}$, $\{01 \overline{1} 2\},\{01 \overline{1}\},\{11 \overline{2} 2\}$ and $\{02 \overline{2} 1\}$ incomplete pole figures were measured. The data were then analysed using the Arbitrarily Defined Cells (ADC) method with Labotex software to calculate the complete pole figures. The pole figures are plotted on the plane defined by the shear direction (SD: vertical axis) and the radial direction (RD: horizontal axis). Classically, the torsion texture orientations are labeled $\{$ hkil $\}<\mathrm{uvtw}>$, where $\{$ hkil $\}$ is a plane parallel to the shear plane and $<$ uvtw $>$ is a direction parallel to the shear direction.

Tensile specimens were cut from samples processed by 5 turns of HPT. To avoid any problems associated with the occurrence of microstructural inhomogeneities in the centres of the discs, these tensile specimens were prepared using electro-discharge machining where two separate specimens were cut from each disc and these specimens were placed symmetrically on either side of the centre of the disc with the central point of each sample located at $2 \mathrm{~mm}$ from the disc centre [14]. The samples were homogenised at the testing temperature for $\sim 15$ minutes prior to tensile testing and the testing temperature was held constant to within $\pm 2 \mathrm{~K}$. The miniature tensile specimens had gauge lengths of $1.1 \mathrm{~mm}$ and widths of $1.0 \mathrm{~mm}$. All tensile specimens were pulled to failure at 623 and $673 \mathrm{~K}$ using a Zwick $30 \mathrm{KN}$ Proline testing machine operating at a constant rate of crosshead displacement with initial strain rates of $4.5 \times 10^{-5}, 1.3 \times 10^{-4}, 1.3 \times 10^{-3}$ and $1.3 \times 10^{-2} \mathrm{~s}^{-1}$. The gauge lengths after tensile testing were measured using an Olympus BX51 microscope.

\section{Experimental results}

Figure 1 shows the measured values for the Vickers microhardness, Hv, after room temperature HPT processing 


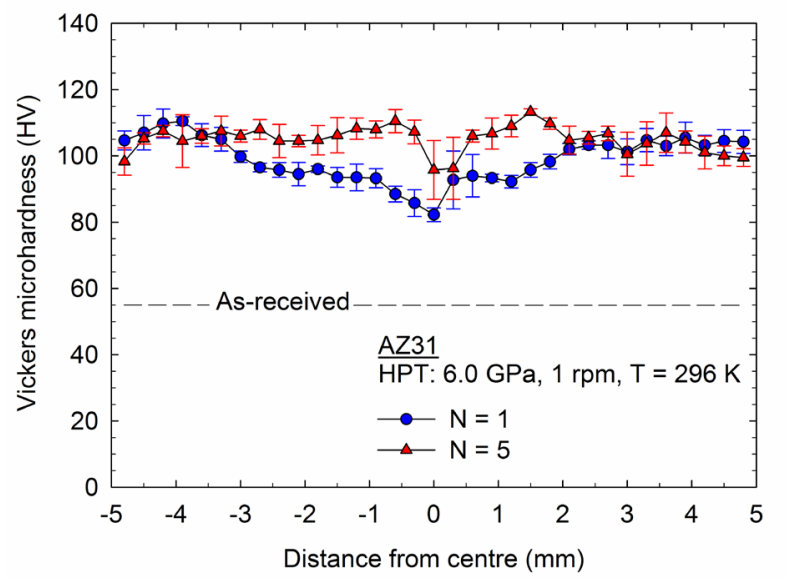

Fig. 1. Distribution of Vickers microhardness, Hv, along the diameter of discs processed by HPT through 1 and 5 turns.

through 1 and 5 turns, where individual datum points are plotted as a function of the distance across each disc. At the outer edges of the discs the hardness values remain constant with increasing straining but in the central region there is a clear increase in hardness with increasing numbers of turns. This plot shows the hardness values for 1 turn lie consistently below the hardness values for 5 turns, and the hardness tends to have a more uniform distribution along disc diameter after 5 turns processing.

The hardness values are consistent with the corresponding microstructure features at $296 \mathrm{~K}$ reported earlier [15-18] where the finer grain size at the disc centre and half-radius areas after 5 turns leads to higher hardness values than its counterpart processed by 1 turn and the similar ultrafinegrain sizes at the disc edge after 1 and 5 turns lead to similar hardness values.

Figure 2 shows the microstructure before HPT processing and after 5 turns of room temperature HPT processing at the
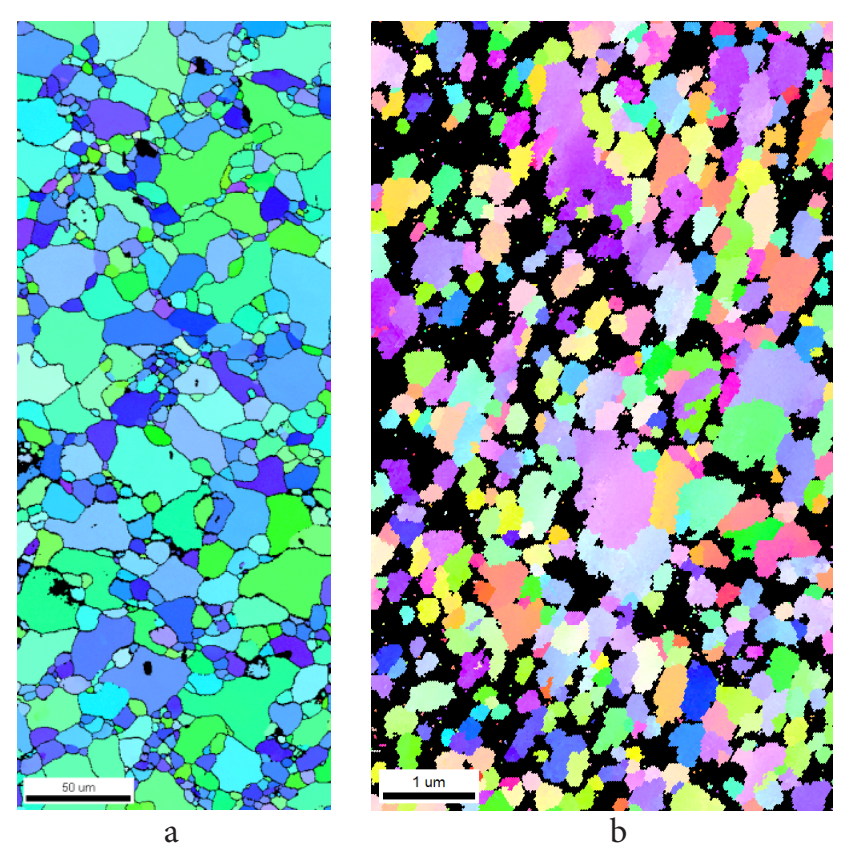

Fig. 2. Microstructure of (a) as-received material and (b) disc processed to 5 turns by HPT.

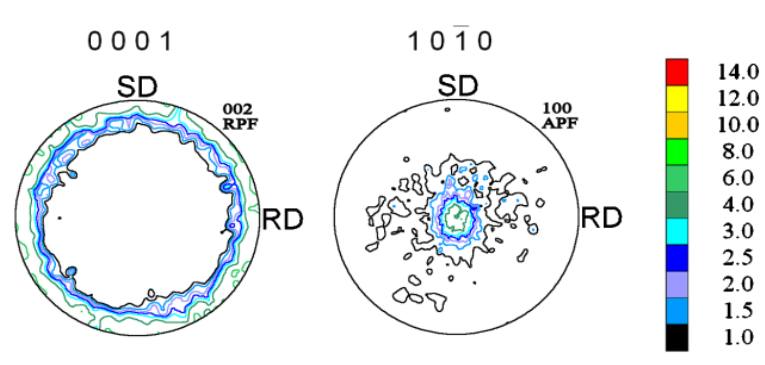

a
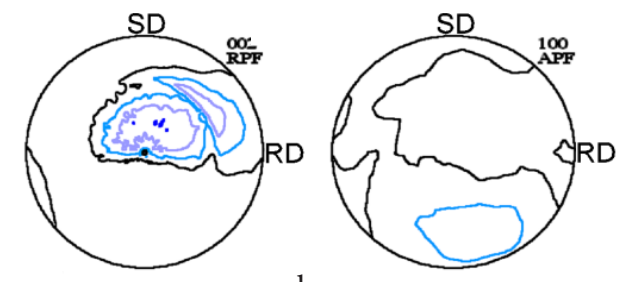

b

Fig. 3.X-ray diffraction results: $\{0001\}$ and $\{10 \overline{1} 0\}$ pole figures in (a) the as-received AZ31 alloy and (b) 5 turns disc processed by HPT.

disc edge area. In the unprocessed condition as shown in Fig. $2 \mathrm{a}$, the average grain size was $\sim 10 \mu \mathrm{m}$. After 5 turns of HPT processing, the grain size was reduced to $\sim 450 \mathrm{~nm}$ as shown in Fig. 2b. Obviously, significant grain refinement in AZ31was attained after room temperature HPT processing to 5 turns.

Figure $3 \mathrm{a}$ shows the $\{0001\}$ and $\{10 \overline{1} 0\}$ pole figures for the as-received AZ31. X-ray diffraction results demonstrate that the initial texture is fibre which means the hcp crystal $\mathrm{c}$-axis is in the (SD, RD) plane of the disc and therefore perpendicular to the HPT torsion axis. Figure 3(b) displays the global textures after HPT processing at room temperature for 5 turns. The textures of room temperature HPT sample are made up of two components: the main $\{0001\}<$ uvtw $>$ fibre and second fibres. The majority of hcp crystal c-axis during room temperature HPT rotates from initially perpendicular to the HPT torsion axis to a position which is closer to parallel to the HPT torsion axis so that the basal plane is parallel to the HPT processed disc surface.

The stress-strain relationships from tests carried out at 623 and $673 \mathrm{~K}$ with initial strain rates of $4.5 \times 10^{-5}, 1.3 \times 10^{-4}, 1.3 \times 10^{-3}$ and $1.3 \times 10^{-2} \mathrm{~s}^{-1}$ for 5 turns HPT samples are brought together in Fig. 4. The lower the strain rate, the lower the flow stress. At a constant temperature, the strain corresponding to the peak stress (the peak strain) increases with decreasing strain rate. At both test temperatures (623 and $673 \mathrm{~K}$ ) there is evidence of some initial hardening followed by softening until failure.

The strain rate sensitivities quoted here were determined directly from the log (stress) vs log (strain rate) plot. To obtain continuity in strain rate sensitivity values, calculations were made at peak stress to ensure that no effect of plastic instability affected the calculated values. Fig. 5 gives the strain rate sensitivity variations obtained from tests carried out at 623 and $673 \mathrm{~K}$, respectively. The results show that, with strain rates of $1.3 \times 10^{-2}$ and $1.3 \times 10^{-3} \mathrm{~s}^{-1}$, the average $\mathrm{m}$ value was $\sim 0.10$ at both 623 and $673 \mathrm{~K}$; with strain rates of $1.3 \times 10^{-3}$ and $1.3 \times 10^{-4} \mathrm{~s}^{-1}$, the average $\mathrm{m}$ value varied between 0.2 and 0.3 with temperatures of 623 and $673 \mathrm{~K}$. With a strain rate of $1.3 \times 10^{-4}$ and $4.5 \times 10^{-5} \mathrm{~s}^{-1}$, the average $\mathrm{m}$ value was $\sim 0.3$ at a temperature of $673 \mathrm{~K}$. The maximum strain rate sensitivity, 


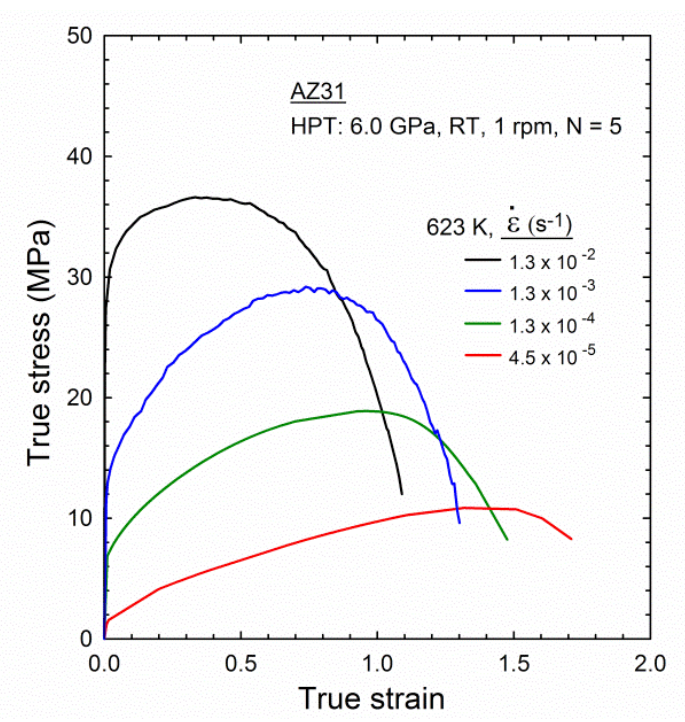

a

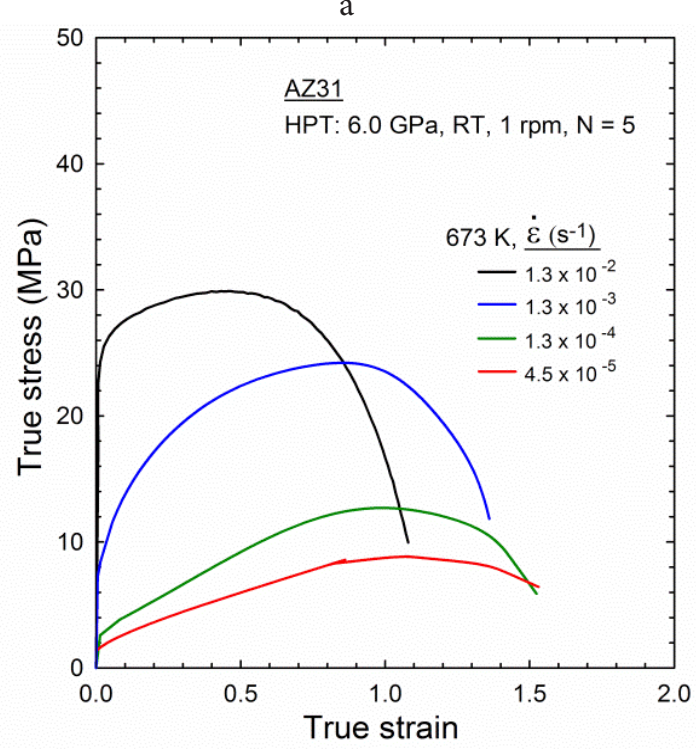

$\mathrm{b}$

Fig. 4. True stress vs true strain rate for HPT processed AZ31 tested at (a) 623 and (b) $673 \mathrm{~K}$.

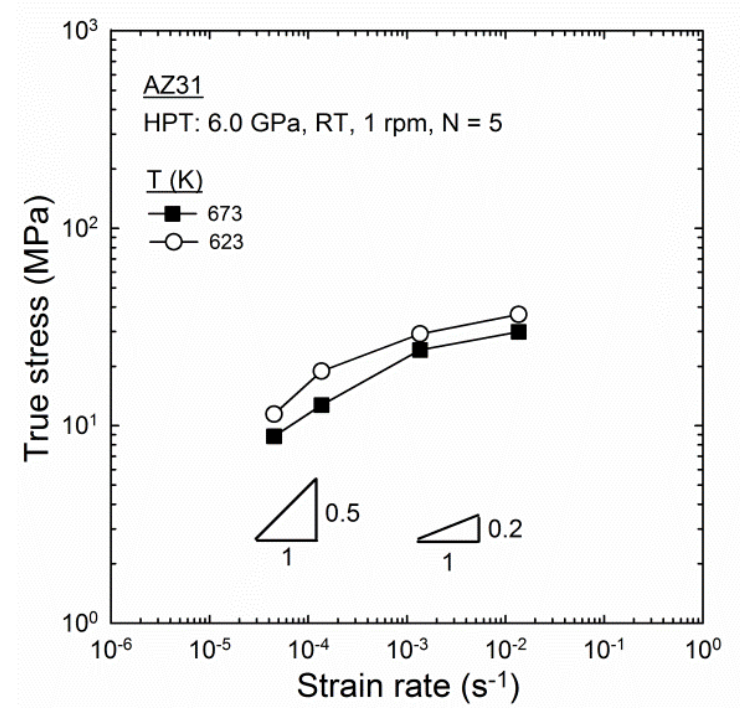

Fig. 5. True stress vs true strain for HPT processed AZ31 tested at (a) $623 \mathrm{~K}$ and (b) $673 \mathrm{~K}$.

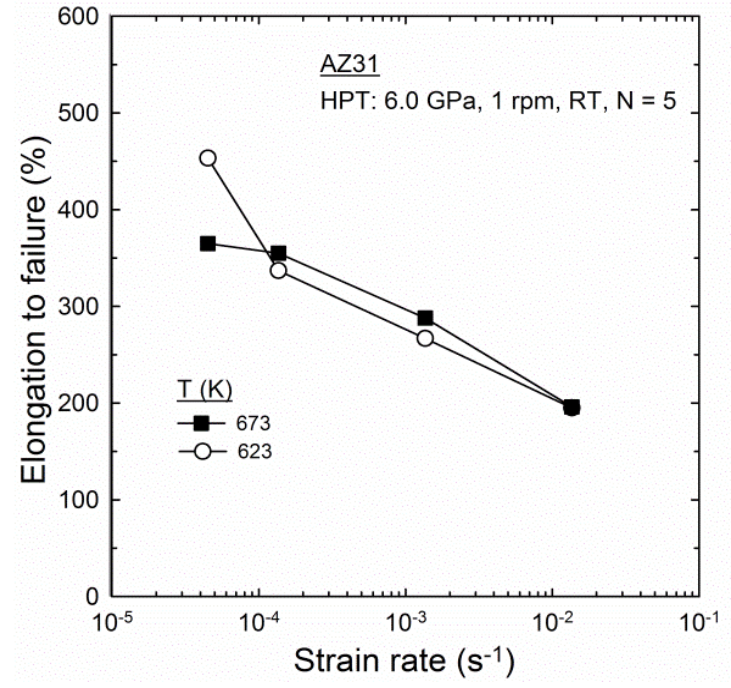

Fig. 6. Elongation to failure vs strain rate for HPT processed AZ31 tested at 623 and $673 \mathrm{~K}$.

0.45 , was obtained at $623 \mathrm{~K}$ with strain rates of $1.3 \times 10^{-4}$ and $4.5 \times 10^{-5} \mathrm{~s}^{-1}$.

The elongations to failure with different strain rates are shown in Fig. 6. At the fastest strain rate of $1.3 \times 10^{-2} \mathrm{~s}^{-1}$, there are similar elongations of $\sim 196 \%$ at both 623 and $673 \mathrm{~K}$. At the strain rate of $1.3 \times 10^{-3} \mathrm{~s}^{-1}$, the material shows elongations of $\sim 265 \%$ and $\sim 290 \%$ at 623 and $673 \mathrm{~K}$ respectively. As the strain rates decreases to $1.3 \times 10^{-4} \mathrm{~s}^{-1}$, the elongations are $\sim 335 \%$ at $623 \mathrm{~K}$ and $\sim 355 \%$ at $673 \mathrm{~K}$. It is obvious in Fig. 5 that at the strain rates $1.3 \times 10^{-3}$ and $1.3 \times 10^{-4} \mathrm{~s}^{-1}$ the elongations at $673 \mathrm{~K}$ are slightly longer than at $623 \mathrm{~K}$. At the slowest strain rate of $4.5 \times 10^{-5} \mathrm{~s}^{-1}$, the material shows the longest elongation of $445 \%$ at $623 \mathrm{~K}$ but with a lower elongation of $\sim 365 \%$ at $673 \mathrm{~K}$. The elongation is higher than $400 \%$ at $623 \mathrm{~K}$ when testing at $4.5 \times 10^{-5} \mathrm{~s}^{-1}$ showing the occurrence of superplasticity.

\section{Discussion}

Room temperature HPT processing of AZ31 refined the grain size from an initial value of $10 \mu \mathrm{m}$ to $\sim 450 \mathrm{~nm}$ after 5 turns processing as shown in Fig. 2b. There was a report on ECAP processing of AZ31 at $473 \mathrm{~K}$ using a $110^{\circ}$ die [11] and processing route was $\mathrm{Bc}$ and the billet processed for 4 passes refined the grain size from an as-received value of $6.5 \mu \mathrm{m}$ to $\sim 3.6 \mu \mathrm{m}$. Obviously, HPT processing is capable of introducing significant grain refinement compared to the ECAP processing of AZ31.

In an earlier study [11], the ECAP billets were cut parallel to and perpendicular to the rolling direction from the asreceived rolled slab. Both orientation billets were processed by ECAP and then tensile tested at 623 and $673 \mathrm{~K}$ with initial strain rates of $1.0 \times 10^{-4}, 1.0 \times 10^{-3}$ and $1.0 \times 10^{-2} \mathrm{~s}^{-1}$. The elongations to failure for these different specimens are shown in Fig. 7. The elongations are higher than $400 \%$ at both 623 and $673 \mathrm{~K}$ when testing at strain rates of $1.0 \times 10^{-4}$ and $1.0 \times 10^{-3} \mathrm{~s}^{-1}$ thereby confirming the occurrence of true superplasticity in ECAP processed AZ31.

When comparing tensile elongation results from HPT 


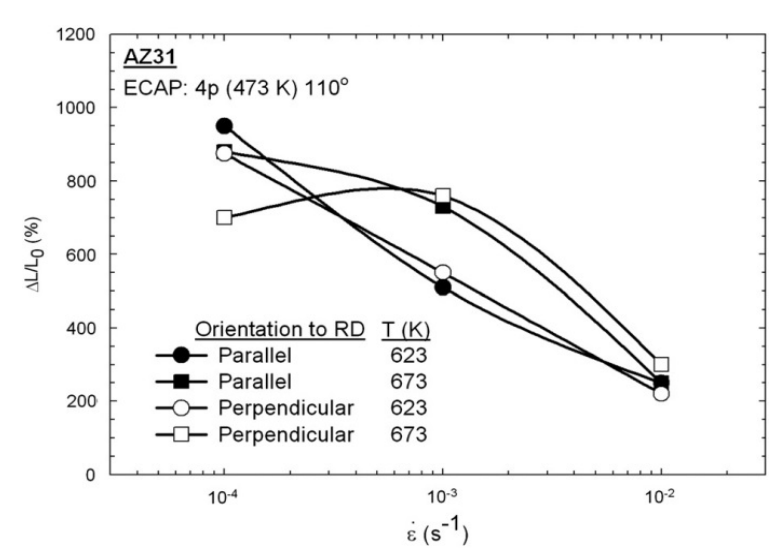

Fig. 7. Elongation to failure as a function of strain rate at 623 and $673 \mathrm{~K}$ for specimens processed by ECAP parallel and perpendicular to $\mathrm{RD}[11]$.

processed AZ31 in Fig. 6 with the tensile elongation results from ECAP processed AZ31 in Fig. 7, it is apparent that the ECAP processed AZ31 has elongations more than $400 \%$ at strain rates of $1.0 \times 10^{-4}$ and $1.0 \times 10^{-3} \mathrm{~s}^{-1}$ with temperatures of 623 and $673 \mathrm{~K}$; whereas the HPT processed AZ31 only attains elongations more than $400 \%$ at the slowest strain rate of $4.5 \times 10^{-5} \mathrm{~s}^{-1}$ with a temperature of $623 \mathrm{~K}$. Obviously, at same test temperatures of 623 or 673 $\mathrm{K}$ the HPT processed AZ31 has lower elongations than ECAP processed AZ31 at strain rates around $1.0 \times 10^{-4}$, $1.0 \times 10^{-3}$ and $1.0 \times 10^{-2} \mathrm{~s}^{-1}$.

Normally, if material has finer grain size it would expect material has good superplastic behavior. HPT processed AZ31 has finer grain size but lower elongations at 623 and $673 \mathrm{~K}$, whereas ECAP processed AZ31 has coarser grain size and longer elongations at temperatures of 623 and $673 \mathrm{~K}$. The reason for lower elongations in HPT processed AZ31 may be related to the thermal stability of HPT processed microstructures, texture and tensile specimen size.

Since the tensile specimens were held at the testing temperature for $\sim 15$ minutes prior to the tensile testing, it is necessary to know the thermal stability of HPT processed AZ31. There is a recent result on the examination of annealed microstructures of room temperature HPT processed 5 turns samples after annealing at 423,473, 573 and $673 \mathrm{~K}$ for $1800 \mathrm{~s}$ [19]. Fig. 8 shows the microhardness and grain size as a function of the annealing temperature. The material undergoes recovery up to $423 \mathrm{~K}$, recrystallization at $423 \mathrm{~K}$ and grain growth at higher temperatures. Obviously, after $1800 \mathrm{~s}$ heating at 573 and $673 \mathrm{~K}$ the grain sizes grow to $\sim 3.5 \mu \mathrm{m}$ and $\sim 5$ $\mu \mathrm{m}$ in turn [19]. Based on the grain sizes shown in Fig. 8, room temperature HPT processed AZ31 has quickly lost its ultrafine-grained structure after short time heating at 573 and $673 \mathrm{~K}$. At $573 \mathrm{~K}$ annealing, the grains grow to grain sizes of $\sim 3.5 \mu \mathrm{m}$ which is similar to the grain size of $\sim 3.6 \mu \mathrm{m}$ in ECAP processed AZ31. Because of more significant grain growth at $673 \mathrm{~K}$ (with grain size $\sim 5 \mu \mathrm{m}$ ) than at $623 \mathrm{~K}$, at the slowest strain rate of $4.5 \times 10^{-5} \mathrm{~s}^{-1}$ and $673 \mathrm{~K}$ the AZ31 does not show the superplastic elongation of $>400 \%$ as at $623 \mathrm{~K}$.

When the mechanical properties of magnesium alloys that have strong crystallographic texture are investigated,

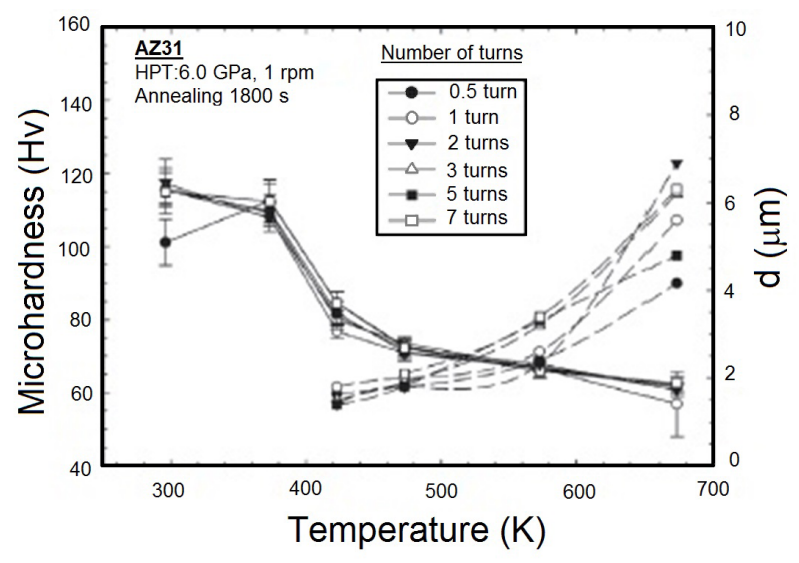

Fig. 8. Microhardness and grain size of the HPT processed AZ31 as a function of annealing temperature [19].

a consideration of the crystallographic orientation in addition to the grain size is important [20]. It is well known that a strong basal texture is responsible for the intrinsic plastic anisotropy, low elongation and poor formability [21]. Fig. 3 shows that the room temperature HPT processed 5 turns sample has the main $\{0001\}<$ uvtw $>$ fibre. This means most grains having the main $\{0001\}<$ uvtw $>$ fibre will have their $\mathrm{c}$-axis parallel to the HPT torsion axis. It also means that in tensile specimens most grains having the main $\{0001\}<$ uvtw $>$ fibre will have their basal plane parallel to the surface of the tensile specimen. Under this deformation condition, the ductility is expected to be small because the critical resolved shear stress does not operate on the basal plane due to the small Schmid factor that is nearly zero.This indicates the main $\{0001\}<$ uvtw $>$ fibre makes contributions to the low elongations at 623 and $673 \mathrm{~K}$ of the HPT processed AZ31.

The geometry of specimens should meet the American Society for Testing and Materials (ASTM) standard [22]. However, sometimes sample sizes cannot fit the ASTM standard, and non-standard miniature dog-bone tensile specimens with different thicknesses and geometries are frequently used to explore the tensile behavior, especially for samples with nanometer or submicron-sized grains. The ECAP tensile specimen has a gauge size of $4 \times 3 \times 2 \mathrm{~mm}^{3}$ (length, width, thickness) [11] whereas HPT tensile specimens have gauge sizes of $1.1 \times 1.0 \times 0.65-0.70 \mathrm{~mm}^{3}$ (length, width, thickness). There is no significant difference for the ratio between the gauge length to gauge width between the ECAP and HPT tensile specimens and the major difference is the specimen thickness. It was reported that the yield and tensile strengths decreased when the number of grains over the thickness was decreased and the ductility also decreased when reducing the thickness $[23,24]$. Obviously considering the effect of specimen thickness on mechanical properties, it is reasonable to assume that specimen size has certain contributions to the low elongations in HPT processed AZ31 at 623 and $673 \mathrm{~K}$ with different test strain rates. 


\section{Summary and conclusions}

1. HPT is a feasible method for achieving grain refinement and strength improvement in the AZ31 alloy. Through room temperature HPT processing to 5 turns, the AZ31 grains were refined from $10 \mu \mathrm{m}$ to $\sim 450 \mathrm{~nm}$.

2. HPT processed AZ31 samples showed essentially no superplastic elongations at strain rates of $1.3 \times 10^{-4}$, $1.3 \times 10^{-3}$ and $1.3 \times 10^{-2} \mathrm{~s}^{-1}$ with 623 and $673 \mathrm{~K}$ testing temperatures. Only at $4.5 \times 10^{-5} \mathrm{~s}^{-1}$ and $623 \mathrm{~K}$ an exceptional elongation of $445 \%$ was achieved.

3 . The low elongations in HPT processed AZ31 are related to the material thermal stability, the texture component and the tensile specimen size.

Acknowledgements. This work was supported by the European Research Council under ERC Grant Agreement No. 267464-SPDMETALS.

\section{References}

1. R. Lapovok, Y. Estrin, M.V. Popov, S. Rundell, T. Williams, J. Mater. Sci. 43, 7372 (2008).

2. R.Z. Valiev, R.K. Islamgaliev, I.V. Alexandrov, Prog. Mater. Sci. 45, 103 (2000).

3. R. Z. Valiev, T. G. Langdon, Prog. Mater. Sci. 51, 881 (2006).

4. A.P. Zhilyaev, T.G. Langdon, Prog. Mater. Sci. 53, 893 (2008).

5. A.P. Zhilyaev, B.K. Kim, G.V. Nurislamova, M.D. Baró, J.A. Szpunar, T.G. Langdon, Scr. Mater. 46, 575 (2002).

6. A.P. Zhilyaev, G.V. Nurislamova, B.K. Kim, M.D. Baró, J.A. Szpunar, T.G. Langdon, Acta Mater. 51, 753 (2003).
7. A.P. Zhilyaev, B.K. Kim, J.A. Szpunar, M.D. Baró, T.G. Langdon, Mater. Sci. Eng. A 381, 377 (2005).

8. T.G. Langdon, Metall. Trans. 13A, 689 (1982).

9. R.B. Figueiredo, T.G. Langdon, Mater. Sci. Eng. A501, 105 (2009).

10. R.B. Figueiredo, T.G. Langdon, J. Mater. Sci. 45, 4827 (2010).

11. R.B. Figueiredo, T.G. Langdon, Mater. Sci. Eng. A556, 211 (2012).

12. P. Serre, R.B. Figueiredo, N. Gao, T.G. Langdon, Mater. Sci. Eng. A528, 3601 (2011).

13. R.B. Figueiredo, P.H.R. Pereira, M.T.P. Aguilar, P.R. Cetlin, T.G. Langdon, Acta Mater. 60, 3190 (2012).

14. A. Loucif, R.B. Figueiredo, M. Kawasaki, T. Baudin, F. Brisset, R. Chemam, T.G. Langdon, J. Mater. Sci. 47, 7815 (2012).

15. Y. Huang, R.B. Figueiredo, T. Baudin, F. Brisset, T.G. Langdon, Adv. Eng. Mater. 14, 1018 (2012).

16. Y. Huang, R.B. Figueiredo, T. Baudin, A.-L. Helbert, F. Brisset, T.G. Langdon, J. Mater. Sci. 47, 7796 (2012).

17. Y. Huang, R.B. Figueiredo, T.G. Langdon, Rev. Adv. Mater. Sci. 31, 129 (2012).

18. Y. Huang, R.B. Figueiredo, T. Baudin, A.-L. Helbert, F. Brisset, T.G. Langdon, Mater. Res. 16, 577 (2013).

19. L.R.C. Malheiros, R.B. Figueiredo, T.G. Langdon, J. Mater. Res. Tech. 4, 14 (2015).

20. Y. Yoshida, L. Cisar, S. Kamdo, Y. Kojima, Mater. Trans. 44, 468 (2003).

21. B. Zhang, Y. Wang, L. Geng, C. Lu, Mater. Sci. Eng. A539, 56 (2012).

22. http://www.astm.org

23. C.H. Suh, Y.C. Jung, Y.S. Kim, J. Mech. Sci. Tech. 24, 2091 (2010).

24. L. Yang, L. Lu, Scripta Mater. 69, 242 (2013). 